\title{
A Review on Writings on Religious Tolerance in Malaysia
}

\author{
RUHAIZAH ABDUL GHANI* \& JAFFARY AWANG ${ }^{1}$
}

\begin{abstract}
Living in a multi-religious and multi-cultural country like Malaysia is a very challenging experience. It requires understanding and cooperation among the races so as to ensure good relations. The race relations developed gradually and went through various stages throughout the history based on the political and the social circumstances of the society. Throughout the history, authors were inspired to write about the development of the race relation from one stage to the next until it proceeded to write about religious tolerance. This paper examines the writings on religious tolerance in Malaysian settings. By using the historical approach, it analyses the pattern of writings from the early stage of race relations to the evolvement of specific writings on religious tolerance. The issue of religious tolerance captured researchers' and writers' attention during the 2000s due to the incident of 11th September 2001 and the global phenomenon of Islamophobia which affected public perception of Islam and Muslims. The ill-informed public perception created discomfort among the different religions in Malaysia. At worst it could cause race conflicts. Hence, efforts were made by concerned authors to write regarding the issue with the aim of removing the prevalent prejudice and misconception about Islam and Muslims and to enhance religious tolerance as the vital element for sustaining good relations among the races.
\end{abstract}

Keywords: interfaith relation, Malaysian society, race relations, religious tolerance

Malaysia is well known for its a pluralistic nature. Malaysia's plurality is one of race, language, and religion. Before the colonial era, society in the Malay archipelago consisted of various minority ethnic groups (originated from Jawa, Sumatera, Arabia and so forth). Society was pluralistic, and the races were integrated and assimilated into the dominant society that was native-based Malayan culture (Ghazali 1970; Abdul Rahman 2002). The contact between the Malay world and other major civilisations took place in a very natural and harmonious way. This is evident from the interaction that took place among the indigenous people and those who came to Malaya as traders, travellers, religious preachers and so on from Arabia, India, China, as well as other parts of the Malay Archipelago. (Abdul Rahman 2002). The emergence of the BabaNyonya community who speak Malay and wore the Malay attire but at the same time secured their ancestors' belief (Roff 1967; S. Husin 1984 2008; Gullick 1989; Abdul Halim 2009) could be an example of the harmonious interaction that happened between the members of the pluralistic Malay society.

Similarly, the peaceful situation was maintained during the early period of colonisation, whereby the relationship among three main races was cordial and harmonious especially before the migration of labour from India and China (Rupert 1970). The British policy of encouraging

\footnotetext{
${ }^{1}$ Ruhaizah Abdul Ghani*(Corresponding author), M.A., lecturer at Academy of Islamic Contemporary Studies, Universiti Teknologi MARA (UiTM) Cawangan Terenganu, Sura Hujung, 23000 DUNGUN, Terengganu, Malaysia, email: rhaizah@tganu.uitm.edu.my; Jaffary Awang, Ph.D., assoc. professor at Dept. of Theology and Philosophy, Universiti Kebangsaan Malaysia, 43600 BANGI, Selangor, Malaysia, email: jaffary@ukm.edu.my.
} 
the migration of Chinese and Indian to the Malaya Archipelago to fulfil the needs of the labour force in mining and agriculture sectors changed the demographic background of the land. A huge number of Chinese and Indian migrants occupied Malaya bringing along their religions and cultures. This created a situation which forced the society to live side by side with the others of distinctive religious and cultural backgrounds (Shuhaimi 2009).

The colonialist power applied the rules that resulted in less interaction among these three major races. It segregated their settlement on an occupational basis. The Chinese occupied the urban area as they worked at tin mines, the Indian settled at the estate working as rubber tapper and the Malay as the indigenous race stayed at the rural area living as farmers, fishermen as well as collectors of forest products. The interaction among the races only took place where Malays and plantation workers occupied the rural areas (Khoo 1994; Azmah 2001; Cheah 2009). Pluralism did not affect the peaceful life in Malaya because of the minimal level of interaction between the different races

Regardless of Furnivall's (1948) idea of negating conflict among the races, the divide and rule policy had a negative impact on the race relations such as less interaction and economic disparities. These impacts lead to further race conflict. Less interaction would slowly instil prejudices among them. Malays as the land owner were seen as having low intelligence, lazy and with no mission in life (Hussein al-Attas 1977; Razaleigh 2012). The Chinese were viewed as liars in business and being money and profit oriented (Syed Husin 2008; Mohd Azhar et al. 2012. This scenario became worse after the Japanese invasion because of race discrimination. From 1931-1937, there was a serious conflict between Japan and China, and it prevailed in Malaya which deteriorated the relation between the Japanese and Chinese to the extent that the Chinese were killed. Compared to the Chinese, Malays were given privilege as a means to get their support as well as to win the war against the other colonialists. Then, when Japan lost in August 1945, the Chinese retaliated by killing Malays who cooperated with Japan.

During the second phase of British rule, the races started to think of administering their country and initiated the effort of cooperating with each other in politics. Each group aimed at securing its needs besides the ultimate objective of gaining independence. With the spirit of cooperation and tolerance, they agreed to secure a special position for the Malays, recognising them as the earliest residents and Islam was declared as an official religion. On the basis of equality, the other races enjoyed religious freedom (Wan Hasyim 1983; Hussin 1990; Zainal Abidin 2005; Cheah 2009). This strong coalition was able to convince the colonialists that they were capable of governing the country independently. As a result of their efforts, they were able to achieve their ultimate goal of independence in 1957. Throughout post-independence, races were at the best level of their relation to ensure the non-existence of conflict between them irrespective of the prejudices of one race over others. However, good relation of races was interrupted by the riot of $16^{\text {th }}$ May 1969, in which many Chinese were killed. After this incident, continuous efforts were made to mend the good relation and make sure such a riot will never happen again.

In the practice of various belief systems and religions, society needs to adapt to the situations that lead to the maintenance of security and harmonious coexistence among the races of different cultural backgrounds and religious orientations. Concerted efforts should be made to ensure the difference among the races would not result in conflict in the society. One of the methods through which peace and harmony can be achieved in a society is the practice of religious tolerance. The practice of religious tolerance in Malaysia is the continuation of the earliest efforts taken by the society in maintaining peaceful and harmonious coexistence among different races. Some authors have portrayed Malaysia as an exemplary country for successful maintenance of peace and harmony through the practice of religious tolerance (Yousif 1998; Osman Bakar 2006). Based on the history of race relations in Malaysia, this paper analyses the literary works on religious tolerance that initially started with the concern for achieving good relations among the different races. 


\section{Analytical Discussion of Literary Works of Religious Tolerance in Malaysia}

Religious tolerance is a global issue that has been discussed over decades (Smith 1990; Schmidt 2002; Pasamonik 2004;Byrne 2011; Ahmad Tarmizi Talib \& Sarjit S. Gill 2012). This issue is normally discussed in a society that consists of ethnic groups with a different religion, culture and way of living such as Malaysia. In Malaysia, the discussion of tolerance started before the independence of the country, since interaction among people took place during the early period of the Malay kingdom whereby two major Asian civilisations i.e. China and India met through trade (Abdul Rahman 2002).

Before the colonial era, there was established interaction between Malay society and the foreigners who went there as traders. It happened in a very natural way without involving any element of compulsion or force by either party, hence, accepting their differences with an open mind and paving the way for peaceful social life. With the beginning of colonialism, the colonialists imposed their policy to optimise the acquisition of the natural resources of the land which brought profit to their economy. British rule introduced a policy to bring in workers from China and India. This policy created a pluralistic society because these immigrants brought together with them their ancestors' heritage including religion, faith and cultures (Wan Hasyim 1983;S.Husin 1984). Although these immigrants lived together, it was unfortunate that they did not mix. They distinctively held different beliefs, practised different rites and rituals. (Furnivall 1956) This newly formed society, therefore, required the people of the land to tolerate these immigrants.

The other policy was to segregate race based on the job. Though it led to reduced levels of social interaction, the social interaction somehow remained prevalent in the workplaces, market and recreational areas (Furnivall 1956; Khoo 1994; Osman Bakar 2006). This relation extended to politics and it became more serious when the races started working together towards achieving the goal of independence. Their tolerance and mutual understanding in setting up race-based parties succeeded in gaining the trust of the people. This struggle ended with the ultimate success of achieving nationhood in 1957.

Based on this scenario, the literature on religious tolerance had two different patterns. The first pattern focuses on the relations among the races. The early works within the 60s through to the 80s did not specifically touch on the topic of tolerance, but they dealt with the issue of race relations (Roff 1967; Rupert 1970; Chew 1979; Wan Halim 1982; Wan Hasyim 1983). We find the issue of race relations in books written about Malaya and its society. It concentrated much on Malaysian society and the good interaction among the different races that resulted in a harmonious and peaceful life among them (Roff 1967; Rupert 1970). However, the discussion was not extensively detailed exploring the real scenario of the society that portrayed the interaction of the races. Roff's work is considered the first work written about the history of Malays in modern times. Other writings focused on the practice of the colonialists but not on their impact on the native life. He elaborated Malays' different aspects of life in detail such as economic, politic and the social scenario that resulted from the British policies (Roff 1967). Since the focus of his work was in the Malay society, he mentions little about the race relation sufficing by mentioning the harmonious relation between the races.

Rupert (1970) stated that the relationship between the people of different races was harmonious, but no specific scenario was given to portray that situation. The reality of harmony was left hanging. The interpretation offered by Mahathir provided us with one possible answer about harmony. Mahathir (1982) interpreted the meaning of harmonious life based on the real context of Malaysian society. He explained the harmony did not reflect total freedom from conflict; it only reflected the non-existence of open conflicts and major discomfort.

After the 16 May 1969 riot, the writings stressed the formation and sustainability of good relation among the races. This was specifically meant to expedite the process of achieving national integration. Thus, the major focus of the books written at that time was to enhance good 
social relations among different races toward achieving national integration (Chew 1979; Wan Halim 1982; Wan Hasyim 1983). Chew (1979) was concerned with the social and cultural aspects of race relations which could be seen as the major factors of conflict between races. Based on the macro analysis of the races especially Malay and Chinese, the study examines the social and cultural aspects of the races and their historical backgrounds. A comparative study of both races was undertaken to normalise the races relation and achieve national integration. Chew also discussed the influence of the West on the social and cultural life of the locals and the steps undertaken by the government in solving the racial problem. Regardless of the detailed comparative study of both races in terms of their socio-cultural life, the works, however, did not elaborate on the aspect of tolerance which constitutes an important element in the fabric of race relation.

Wan Halim (1982) expressed concern regarding the racial issue which might hinder national integration. In analysing various aspects of race relations, he viewed them as possible factors of conflict between different races. For instance, from religious aspects, the values found in different religions can be the cause of conflict between due to their contradictory nature. For example, slaughtering a cow in Islam is recommended as means for ibadah (worship) during Hari Raya Korban while for the Hindus, it is something very sensitive since to for them the cow is a sacred animal. Through understanding the differences in respect of religious values, they are supposed to enhance mutual respect thus ensuring the formation of good relations among the races. The issue was further discussed in the context of achieving national integration, which proved to be extremely challenging in the case of the existence of continuous conflict among the races. Wan Hasyim (1983) was also concerned with the issue of national integration. His study focused on the period between the early 1900s and early 1970s examining the relation of the races as the possible obstacle to national integration. He also explained the concepts and theories of the sociology of race relations and national integration in the Malaysian context. In achieving the main aim of his work, he used historical and macro sociological approaches. He suggested cooperation between different races through the formation of the political alliance. However, it is unfortunate to see that in his discussion of the formation of the political alliance he did not make any reference to religious tolerance. Similarly, Wan Halim's work did not discuss the issue of tolerance as a possible factor affecting race relations.

The first formal discussion of race relation was initiated on a political basis. It was meant to forge political cooperation through resorting to compromise between the races which could play an important role in achieving the independence of the state. The political alliance provided the races with a platform to interact with each other and work out the focal point which will enable them to compromise their existing differences. According to Ali Mazrui, at the stage of compromise, the dealings among races are not minimal but diverse and interdependent. Even though the races have distinct identities, there is a need for them to compromise so as to achieve peaceful reconciliation between their conflicting interest.(S.Husin 1984)

In the early 90s, the writings were concerned with the factors that were useful in the process of formation and enhancement of races relation such as political cooperation (Hussin 1990; Chandra 1994; Batumalai 1996). It was suggested that the teachings of Islam and the Muslims themselves played important roles in structuring the political system of the state (Hussin 1990). These writings implicitly showed religion to play an extremely significant role in boosting political cooperation among the races. It is due to the teaching of Islam that requires Muslims to have good relations with others, i.e. persons of different beliefs and practices. In contrast to this view, Islamic teaching was viewed by some as the factor that caused discomfort in the Malay Muslims' relation with the others. Islamic teachings have shaped the Muslims' life socially, economically and politically. Internalisation of the Islamic teachings creates high awareness of practising religious life. This situation caused the non-Muslim to feel uncomfortable with the Muslims' attitudes. Batumalai (1996) stressed that Malays' high sensitivity towards religious matters such as halal foods has affected good relations between 
different races. These two opposite effects of practising Islamic teachings requires the Muslim and the non-Muslim to understand each other better especially in respect of belief and the practices of Islam.

The idea of Islamic teachings to be the element that initiated Malay tolerance towards the other races was also agreed by Chandra (1984). In his works, he highlighted the teaching of Islam to have played a great role in shaping the Malay Muslim mentality, hence, influencing their culture, politics and administration Islamic teachings inspired the spirit of tolerance among the Malays towards other races. This was supported by evidence from Quran and the history of previous Muslim nations. There are ample examples of theoretical and practical tolerance in Islam.

It is important to note that in the early 90s, writings on the issue of tolerance were more focused. The discussion was not confined to the issue of tolerance in a certain aspect of life, like political or social, but it was about the general understanding of the concept of religious tolerance. Malaysia has been portrayed as an exemplarity state which can maintain security and peace among multi-ethnic groups, notwithstanding the small and minor conflicts it experienced throughout its history. Even though the political system and its policy of settlement separation contributed to racial polarisation, it did not affect the harmonious relationship among the races. Communication and interaction prevailed among the races in the workplaces, markets and recreational areas. This reflects the fact that Malaysians practice religious tolerance which enabled them to maintain harmonious and peaceful coexistence. This is a situation which is far better compared to other countries (Khoo 1994; Mahathir 1994).

Religious tolerance constitutes a common theme of many contemporary writers (Syed Othman \& Faizal 1994; Mahathir 1994; Mohd Nor Manuty 2009). Mahathir (1994) is concerned with the inter-race conflict which normally occurs within a pluralistic society due to a misunderstanding between Muslim and non-Muslim. Muslims' understanding about other religions are based on teachings that are learned from the Muslim scholars. Knowledge of these scholars are really important and have a great impact on Muslim society. They play important roles in providing correct and true information about other religions as well as information relating to religious tolerance. Lack of information or false information causes misunderstanding and misconception among people thus resulting in conflict and tension among them in the society. For instance, the rejection of Lina Joy's application to renounce Islam by Shariah court negatively affected the non-Muslims' perception about Islamic teachings and the freedom of belief. Moreover, such negative impact resulted in a misunderstanding about Islam. International mass media especially the West portrayed Muslims as terrorists and Islam as a religion that permits terrorism. This false information creates anxiety and fear of Islam among the non-Muslims.

The occurrence of some incidents in the twentieth and twenty-first century brought about some negative consequences pertaining to Islam and Muslims. Muslims are labelled as terrorists and Islam as an intolerant religion. After the 11 September 2001 attack, the phenomena of fear and insecurity dominated global society. This gave rise to the phenomena of Islamophobia in Western society whereby the feeling of insecurity and fear was linked to Muslims. This state of affairs leads to the prevailing misconception about Muslims and Islam. Some tended to judge Islam as a religion that promotes terrorism and Muslims as terrorists.

Malaysian society remained an exception to the misconception. It was also influenced by that situation. A number of incidents took place resulting in discomfort and intolerant behaviour among some individuals which culminated in arsonist attacks. This necessitated the urgent need for the writers to elaborate on the concept and practice of religious tolerance in more critical ways. Muslim scholars being alarmed by the situation came forward to give clear information about the real teaching of Islam. It resulted in the emergence of many specific writings on religious tolerance in the first decade of 2000s (Wan Azizah 2001; Arena et.al 2004; Abdul 
Hamid 2005; Tan Ooi Chee 2005; Naziree 2006; Jaffary 2006a, 2009, 2010a; Khadijah \& Mohd Herzali, 2008; Ammar 2011; A.T.Talib \& Sarjit 2012).

These works appeared in the form of conceptual and theoretical writing (Wan Azizah 2001; Abdul Hamid 2005; Tan Ooi Chee 2005; Naziree 2006; Khadijah \& Mohd Herzali, 2008; Ammar 2011; A.T.Talib \& Sarjit 2012) as well as fieldwork research (Arena et.al 2004; Jaffary $2006,2009,2010$ ). Conceptual writings focused on the elaboration and explanation of principles of religious tolerance based on Islamic sources such as the Quran and Sunnah. Some examples of religious tolerance from the real life of the previous generations as well as from the Malaysian context were given to provide a clear picture of religious tolerance (Usman 2008). Religious tolerance that is practised by Malaysians is closely related to the factors that encourage such tolerance among them. Ibrahim (2013) elaborated that Islamic teachings, as well as other religious teachings, are the main catalyst for religious tolerance. He proved that Islamic teachings initiated and promoted religious tolerance by mentioning some relevant Quranic verses. He also viewed the teachings of other religions in the same light, thus holding them to promote and encourage good relations in the name of religious tolerance.

The freedom of religion is also enshrined in the Constitution of Malaysia. It provides freedom to the adherents of different religions to celebrate their belief related festivals for the purpose of maintaining spiritual peace and tranquillity (Mohamad Zaidi et. al. 2006; Usman 2008; Mohd Shuhaimi 2009; Mohd Roslan 2011; Ammar 2011; A. T. Talib \& Gill S.S 2012; Ibrahim 2013). In other words, they enjoyed the freedom of practising their religion. This freedom caused them to live happily in the religiously pluralistic society. It created a peaceful and harmonious environment in the society. Moreover, explanation of religious tolerance from legal and constitutional aspects is a good effort in considering the role of government in attending the interest of all people irrespective of religion and race (Naziree 2006; Khadijah \& Mohd Herzali 2008; Mohd Roslan 2011).

There are three articles pertaining to the issue of religious tolerance namely; article 11 of the federal constitutional law, where the issue of apostasy and the issue of the word 'Allah' is dealt with. Although Constitutional laws give certain priorities to Malays, it does not neglect or oppress the other races. Every race is equally considered and been given equal right of freedom to practice their religion and uphold their culture. Malay Muslims are supposed to respect their ways of life. Religious tolerance from the constitutional aspect should be elaborated further so as to avoid discomfort and conflict among the communities. Based on the previously stated scenario, the existing relation between different races in the Malaysian context could be described as the relation based on compromise and peaceful coexistence (Khadijah \& Mohd Herzali 2008). Article 11 provides that every person has the right to profess and practice his religion. Every person has the right to propagate his religion, but state law and, in respect of the Federal Territories, federal law may control or restrict the propagation of any religious doctrine or belief among Muslims. However, there is no restriction as regard to the carrying out of missionary works by the Muslims among non-Muslims.

Other cases where religious tolerance could play an extremely important role is in respecting the rights of animals such as dogs and pigs or others which are considered as property by the non-Muslim and should not be violated. Even though there is no specific article in the state law as well as in the constitution providing for the protection of these rights, the Muslims should, by way of practising religious tolerance, avoid violation of non-Muslim property. In short, the element of religious tolerance in Islam should extend to include the prohibition of violation of non-Muslims' rights and properties such as alcohol, dogs and pigs.

On the similar note, the religious tolerance would require the non-Muslim citizens not to conduct business involving these things openly out of concern and respect for the sensitivity of the fellow Muslim citizen. When it comes to the issue of apostasy, it should be a discussion of Muslims only and should not be interfered by others (Naziree 2006). In this respect, both Muslims and non-Muslim must be aware of their limits in the discussion of the religious matter, 
such as what can be discussed openly and what cannot. This is significant especially with respect to sensitive issues on which different religions have taken different positions. For example, pig, dogs and alcohol which Islam declared as probated. Also, the issue of slaughtering cows as an important religious sacrifice in Islam which could be viewed as humiliation by Hindus due to their belief that cows are a sacred animal.

These articles aim to maintain good relations among the different races. Therefore, the discussion of religious tolerance is important to clear the existing misunderstanding among the races. All the non-Malay or non-Muslim should respect the constitution as to be a part of Malaysia. They should understand that religious tolerance aims to find the common values based on which a platform for the formation of a social relation between different races of different religious backgrounds could be built. This would enhance and facilitate a kind of religious tolerance which is conducive to harmonious and peaceful coexistence among difference races.

However, the practice of religious tolerance in Malaysia is obscure due to not being practised broadly in the Malaysian society. Only a few members of the society, among the intellectuals who stay in the urban area, really appreciate and practice religious tolerance (Khadijah \& Mohd Herzali, 2008). The scenario was explored by Ahmad Tarmizi Talib \& Sarjit (2012) who found two contradicting life situations in relation to religious tolerance in the Malaysian context. One situation is represented by the community with high tolerant behaviour; living harmoniously with people of other beliefs and interacting with them. They demonstrated religious tolerance through visiting each other during celebrations of important dates and open houses (Wan Azizah 2001; Mohamad Yusof 2006). While the other situation is represented by a community of a lower level of tolerance, which cannot tolerate the differences thus leading to some unwanted incidents. For instance, in respect of the issue of using the word 'Allah', when the Kuala Lumpur High Court allowed the Herald magazine, a Catholic weekly magazine based in Sabah to use the word 'Allah'. It resulted in discomfort among Muslims hence leading to some unfortunate incidents such as arsonist attacks on churches (Mohd Roslan 2011:23-27). Regardless of the existence of two different groups, it is important to highlight that religious tolerance could only be actualised through mutual respect and understanding.

Fieldwork research on race relations and religious tolerance has also been done to complete the conceptual and theoretical work. Abdul Rahman Embong (2001) briefly discussed race relations by focusing on the middle class as his target group. Race and religion played a crucial role in the formation of the Malay middle-class community. Based on 284 respondents, he categorised Malays into three groups; those who are multi-ethnic and having close relations with other races, visiting them during occasions like an open house. They tried to understand and appreciate other cultures. Their number is small. Those who have no close relation with the other races compared to the first group. They visit their friends or neighbours of different races and religions not as often as the first group. Most of the respondents belong to this category. Those who do not interact with other races and do not try to understand other cultures.

The discussion of religious tolerance in Malaysia proceeds to the practical aspect of social life wherein religious tolerance is applied (Jaffary \& Kamaruddin 2003; Jaffary et. al. 2006a; 2006b; 2009; 2010a; 2010b; Muda Ismail et al. 2009). The Malaysians exposed to different races through work environments such as working in the same office, eating together, and visiting each other demonstrate a high level of religious tolerance. The culture of having an open house during certain occasions underscore the existence of a high spirit of religious tolerance (Wan Azizah 2001; Abdul Hamid 2005; Tan Ooi Chee 2005).

Arena et al. (2004) discussed the approaches which could be used in promoting religious tolerance throughout at all levels of the society including the government, high institutions and schools. The practical tolerance that took place in Malaysian society covers cultural and daily affairs but not in respect of religion. Tolerance requires an attitude of putting aside all the dividing lines between races and religions. All races should accept that their religious difference and interpretation should not influence negatively inter-race relations. 
Students from six national higher institutions (IPTA) were interviewed. The response showed the existence of a minimum level of tolerance between races. Even though some administrators of the institutions initiated efforts to encourage races interaction and intermingling, factors like students' settlement and courses hindered the objective.

Jaffary Awang et al. (2006) researched the Islamic identity, socialisation and religious tolerance among Malay students in National Higher Institutions (IPTA). They discussed the correlation between trends in daily activities with the elements of identity, socialisation and tolerance. Concerning 1213 respondents, the result indicates that students' personality determines socialisation types and levels of tolerance. In another research, Jaffary Awang et al. (2009) studied the contributions of inter-religious dialogue towards the attitude of religious tolerance. It was found that the dialogue was conducive to inculcating the spirit and practice of tolerance. The research focused on the perceptions and attitudes of students' especially UiTM Sarawak towards dialogue and religious tolerance. Based on 240 respondents, the response was positive, and they agreed that dialogue could open a good prospect in instilling the spirit of tolerance. The response also demonstrated Malay students' firm is standing in respect their belief due to high religious awareness, unlike other races.

In such a case, field research identified the level of understanding of religious tolerance and its practice in real life situations. There is a number of researches done in the understanding and practice of religious tolerance (Jaffary \& Kamaruddin 2003; Jaffary et al. 2006a: 2006b: 2009: 2010a: 2010b; Muda Ismail et al. 2009). These researches found that the level of religious tolerance among the respondents was acceptable and satisfactory. The main factor that helped them practice religious tolerance was their religious understanding pertaining to such tolerance. These researches provide a wealth of important information and insight to the practice of religious tolerance in real life situations in the Malaysian context. Even though those studies focused on certain targeted groups and could not be generalised to other groups, it nevertheless provides a reference for further research.

To conclude, the discussions of the issue has been divided into several stages. At the initial stage, it took place during pre- and post-independent Malaysia through to the nineteenth century. The focus during this stage was more on explanation and discussion of the race relation and the factors of its strengthening. The issue of tolerance was less discussed in the political aspect that involved much interaction and cooperation among the races. Later on, it was developed into more detail and critical discussions especially after the incident of 11 September as an answer to the questions of the practical relevance of religious tolerance as a solution to racial conflicts. Moreover, the elaboration is needed to clear misconceptions and prejudice regarding Islam and Muslims. Conceptual writings and field researches can play a crucial role in achieving this goal.

In short, this concept is practically relevant in Malaysia as a method of ensuring good inter-race relationships. More earnest attempts should be made in identifying practices of religious tolerance which are suitable and applicable to Malaysia and which do not contradict the tenets of Islamic teachings.

Since the beginning of independence until the twentieth century, Malaysia's different racial, cultural and religious background enjoyed peaceful and harmonious coexistence. They interacted with each other and established good social relations. It is commonly agreed that Malaysia is more successful in maintaining good relations among its citizens of different races, compared to other multi-racial countries such as Indonesia or Western countries. Due to the stability of the social life, no query regarding the practice of religious tolerance arises, nor the need for the empirical data or field research to prove the reality of the practice is felt. 


\section{References}

Abdul Halim Ramli. 2009. Hubungan Kaum di Malaysia Sejarah dan Asas Perpaduan. Shah Alam: Pusat Penerbitan Universiti (UPENA).

Abdul Hamid Othman.2005. Toleransi agama sebagai teras dialog peradaban. In Azizan Baharudn et. al. (ed.) Dialog Peradaban Peranan dan Kepentingannya di Malaysia. pp. 6270. Kuala Lumpur: Inmind \& Pusat Dialog Peradaban Universiti Malaya.

Ammar Fadzil. 2011. Religious tolerance in Islam: theories, practices and Malaysia's experiences as a Multi Racial Society. Paper presented at Persidangan EASR 4th Conference-SECR 6th Conference Tentang Religious Tolerance and Intolerance, 8-11 September.

Arena Kasim, Muda et.al. 2004. Menjambatkan masyarakat majmuk di Malaysia melalui sikap toleransi. Proceeding of Seminar Pemikiran Islam 2004. pp. 948-961.

Ahmad Tarmizi Talib \& Gill S.S.2012. Religious tolerance exploring the Malaysian experience. Global Journal of Human Social Sciences.12(8): 49-54.

Batumalai. 1996. Islamic Resurgence and Islamization in Malaysia A Malaysian Christian Response. Perak: St. John Church.

Chandra Muzaffar.1984. Has the communal situation worsened over last decade? Some preliminary thought. In S. Husin Ali (ed.). Kaum, Kelas dan Pembangunan Malaysia. pp. 356-382. Kuala Lumpur: Persatuan Sains Soial Malaysia.

1989. Living in multi-ethnic society. In. C. Muzaffar. Challenges and Choices in Malaysian Politics and Society. Penang: Aliran Kesedaran Negara

1987. Islamic Resurgence in Malaysia.Petaling Jaya: Penerbit Fajar Bakti Sdn Bhd.

. 1994. Tolerance in the Malaysian political scene. In Syed Othman al-Habshi \& Nik Mustapha(ed.). Islam and Tolerance. pp. 121-148 Kuala Lumpur: Institut Kefahaman Islam Malaysia.

1996. Accomodation and Acceptance of Non-Muslims Communities within the Malaysian Political System: The Role of Islam. American Journal of Islamic Social Sciences. 13 (1): 28-41.

Cheah, Boon Kheng. 2009. Race and ethnic relation in colonial Malaya during the 1920s and 1930s. Dlm Lim Teck Ghee et.al. (ed.). Multiethnic Malaysia, Past Present and Future. pp. 34-44. Petaling Jaya: Strategic Information and Research Development Centre.(SIRD)

Chew Hock Thye.1979. Masalah Perpaduan Nasional. Kuala Lumpur: Dewan Bahasa dan Pustaka

Ghazali Basri. 1998. A Comparative Study on Religious Tolerance in Post Independence Malaysia and Nigeria with Special Reference to Christian-Muslim Relation. Ph.D. Tesis. University of Aberdeen.

Gullick, J.M. 1964. Malaya. London: Ernest Benn Limited. . 1989. Malay Society in The Late Nineteenth Century. Singapore: Oxford University Press.

Hussin Mutalib. 1990. Islam and Ethnicity in Malay Politics. New York: Oxford University Press. 2010. Religious diversity and pluralism in Southeast Asia Islam: The Experience of Malaysia and Singapore. In Nathan K.S (ed.). Religious Pluralism in Democratic Society. Singapore: Konrad-Adenaeur-Stiftung

Jaffary Awang \& Kamaruddin Salleh. 2003. Toleransi beragama dan perpaduan kaum response intelek Malaysia satu observasi ringkas. In Jaffary Awang (ed.). Agama dan Perpaduan Kaum di Malaysia. pp. 62-75. UKM: Fakulti Pengajian Islam.

Jaffary Awang, Muda@Ismail Ab Rahman, Rofizah Mohammed, Arena Che Kassim, Tengku Ghani Tengku Jusoh \& Muhammad Khatim Hassan 2006a. Identiti Islam, Sosiolisasi dan Toleransi Beragama di Kalangan Pelajar-Pelajar Muslim di IPTA. Paper presented at Seminar Islam dan Hubungan Antara Agama di Malaysia. Organised by Jabatan Akidah dan Pemikiran Islam, Universiti Malaya. 18-19 Jan. 
Jaffary Awang, et. al. 2006b, Pembentukan sikap toleransi beragama, hubungannya dengan kefahaman islam:kajian di kalangan mahasiswa Melayu di IPTA, Proceedings. Wacana Pendidikan Islam (siri 5), Pulau Pinang, 85-90.

Jaffary Awang, Rofizah Mohammed, Arena Che Kassim, Muda@Ismail Ab Rahman, Tengku Ghani Tengku Jusoh \& Muhammad Khatim Hassan. 2009. Toleransi beragama di kalangan pelajar Universiti Teknologi Malaysia. In Jaffary Awang et. al. (ed.). Islam di Era Globalisasi. pp. 200-211. Bangi: Universiti Kebangsaan Malaysia.

Jaffary Awang, Muda@Ismail Ab Rahman, Ahmad Munawar Ismail. 2010a. Toleransi beragama dalam budaya Melayu manifestasi di kalangan mahasiswa Melayu di IPTS. In Yusri Mohammad Ramli et. al. (pnyt). Agama dan Pemikiran Wacana Tradisi Kontemporari Malaysia-Indonesia. pp. 212- 219.UKM: Jabatan Usuluddin dan Falsafah.

Jaffary Awang et al. 2010b. Toleransi beragama dan pola toleransi di kalangan mahasiswa/siswi Melayu di IPTS. Paper presented at Seminar Antarabangsa Agama dan Pembangunan Malaysia dan Indonesia.10-11 June.

Khadijah Mohd Khambali \& Mohd Herzali Haled. 2008. Toleransi Beragama dan Amalannya di Malaysia Merujuk kepada Artikel 11 Perlembagaan Persekutuan Malaysia. Jurnal Usuluddin. Fakulti Usuluddin Universiti Malaya, 81-92.

Khoo, Kim Kay.1994. Tolerance in the Malaysian social scene. In Syed Othman al-Habshi \& Nik Mustapha (ed.). Islam and Tolerance. pp. 149-160. Kuala Lumpur: Institut Kefahaman Islam Malaysia.

Mahathir Mohamed. 1982. Dilema Melayu. Ibrahim Saad (terj). Kuala Lumpur: Federal Publications.

1994. Improving tolerance through better understanding. Dlm. Syed Othman al-Habshi \& Nik Mustapha (ed.). Islam and Tolerance. pp.15-26. Kuala Lumpur. Institut Kefahaman Islam Malaysia.

Mohd Nor Manuty. 2009. Islam dan toleransi budaya dalam masyarakat majmuk di Malaysia; Beberapa Catatan. Kertas kerja Simposium Fiqh Masyarakat Bukan Islam di Malaysia. Anjuran Persatuan Ulama Malaysia Cawangan Selangor, 23-24 December

Mohd Roslan. 2011. Religious tolerance in Malaysia: an overview. Middle-East Journal of Scientific Research. 9(1): 23-27.

Mohamad Zaidi et. al. 2006. Asas toleransi terhadap kebebasan beragama dari perspektif Islam. Paper peresented at Seminar Islam dan Hubungan Antara Agama di Malaysia. Anjuran Jabatan Akidah dan Pemikiran Islam, Universiti Malaya. 18-19 Jan.

Muda @ Ismail \& Farah Salwani. 2003. Toleransi beragama dan Kepelbagaian Budaya di Malaysia. Dlm Jaffary Awang (ed.). Agama dan Perpaduan Kaum di Malaysia. pp. 103-108. UKM: Fakulti Pengajian Islam.

Muda @ Ismail Ab Rahman, et. al. 2009.Sumbangan dialog antara agama-agama di Malaysia terhadap sikap toleransi beragama di kalangan pelajar-pelajar UiTM Sarawak. In Jaffary Awang et. al. (ed.). Islam di Era Globalisasi. Bangi: Universiti Kebangsaan Malaysia,pp.181-187.

Naziree Md. Yusof. 2006. Toleransi Beragama dan Kesesuaian Hukuman Murtad. Ppaer presented at Seminar Islam dan Hubungan Antara Agama di Malaysia. Organised by Jabatan Akidah dan Pemikiran Islam, Universiti Malaya. 18-19 Jan.

Osman Bakar. 2006. Islam dan pengharmonian kehidupan beragama di Malaysia.. Paper presented at Seminar Islam dan Hubungan Antara Agama di Malaysia. Organized by Jabatan Akidah dan Pemikiran Islam, Universiti Malaya. 18-19 Jan.

Roff, W.R.1967.The Origin of Malay Nationalism. London: Yale University Press.

Rupert, E.1970. Malaysia A Study in Direct and Indirect Rule. Kuala Lumpur: University of Malay Press. 
Shuhaimi Haji Ishak. 2009. Cultural and religious tolerance: the Malaysian experience. Kertas kerja Persidangan Conference on Migration, Citizenship and Intercultural Relations. Anjuran Deakin University Australia, 19-20 December.

S.Husin Ali. 1984. Social relation: the ethnic and class factor. In S.Husin Ali (ed.). Kaum, Kelas dan Pembangunan Malaysia. pp.14-24. Kuala Lumpur: Persatuan Sains Soial Malaysia. 2008. Ethnic Relation in Malaysia, Harmony and Conflict. Malaysia: Strategic Infromation and Research Development Center (SIRD).

Tan, Ooi Chee. 2005. Toleransi agama sebagai teras dialog peradaban.In Azizan Baharudin et. al. (ed.) Dialog Peradaban Peranan dan Kepentingannya di Malaysia. pp. 71-76. Kuala Lumpur: Inmind \& Pusat Dialog Peradaban Universiti Malaya.

Usman Muhid. 2008. Prinsip toleransi beragama dalam al-Qur'an kajian surah al-Mumtahinah. Master Disertation. Jabatan Qur'an dan Sunnah, Universiti Malaya.

Wan Azizah Wan Ismail. 2001. Building effective ethical-moral co-operation in a pluralist universe. In Camilleri, Joseph A. (ed.). Religion and Culture in Asia Pacific: Violence or Healing? Melbourne: Pax Christi Australia.

Wan Halim Othman. 1982. Perhubungan kaum dan perpaduan negara di Malaysia. In Zuraina Majid (ed.). Masyarakat Malaysia Tinjauan dan Perbincangan Terhadap Beberapa Isu dan Topik Semasa. Pulau Pinang: Penerbit Universiti Sains Malaysia.

Wan Hasyim Wan Teh.1983. Race Relation in Malaysia. Kuala Lumpur: Heinemann Educational Books (Asia).

Yousif, A.F. 1998. Religious Freedom, Minorities and Islam: An Inquiry into The Malaysian Experience. Selangor: Thinker's Library.

Zainal Abidin Borhan. 2005. Toleransi agama sebagai teras dialog peradaban. In Azizan Baharudn et. al. (ed.) Dialog Peradaban Peranan dan Kepentingannya di Malaysia. Kuala Lumpur: Inmind \& Pusat Dialog Peradaban Universiti Malaya, pp.77-85. 